\title{
Financial and Economic Analysis of a 1-Tonne Capacity Mobile Solar-Biomass Hybrid Dryer for Maize Drying
}

\author{
Joseph Oppong Akowuah*, Ato Bart-Plange, Komla Agbeko Dzisi \\ Faculty of Mechanical and Chemical Engineering, Kwame Nkrumah University of Science and Technology, Kumasi, Ghana \\ Email address: \\ akowuahjoe@yhoo.co.uk (J. O. Akowuah), abartp@yahoo.com (A. Bart-Plange), kadzisi777@gmail.com (K. A. Dzisi) \\ ${ }^{*}$ Corresponding author

\section{To cite this article:} \\ Joseph Oppong Akowuah, Ato Bart-Plange, Komla Agbeko Dzisi. Financial and Economic Analysis of a 1-Tonne Capacity Mobile \\ Solar-Biomass Hybrid Dryer for Maize Drying. International Journal of Agricultural Economics. Vol. 6, No. 3, 2021, pp. 98-105. \\ doi: $10.11648 /$ j.ijae.20210603.11
}

Received: April 24, 2021; Accepted: May 11, 2021; Published: May 20, 2021

\begin{abstract}
Drawbacks associated with natural convection solar dryers are encouraging the development of low-capacity hybrid drying systems which integrate renewable energy in their operation. However, information on the cost-effectiveness of such drying systems for decision-making by investors is lacking. This study seeks to assess the financial and economic feasibility of a solar-biomass hybrid dryer for maize drying. A cost-benefit analysis was done using net present value (NPV), benefit-cost ratio (BCR), and internal rate of return (IRR) as well as payback period to measure the financial viability of the dryer operation and the profitability of the investment. The results show that the total capital expenditure required to establish the drying system is $\$ 5,263$ with a running cost of $\$ 1,166$ per year. Using an economic utilisation period of 10 years, the investment in the dryer was determined to be viable with an NPV of $\$ 4,876$ and an IRR of $38 \%$ at a capital cost of $24 \%$. At a drying charge of $\$ 2.11 / \mathrm{bag}$, the results show the initial capital invested can be recouped in a PBP of 2.7 years at a BCR of 1.48. These financial indicators suggest that investment in the dryer is profitable. Further analysis shows that, at a projected 30, 266.80 tonnes of maize produce per season by smallholder maize farmers in the study area, about 210 of the hybrid dryers are needed to provide drying services to the farmers. This translates into about 420 direct job opportunities created for the youth and the potential to prevent economic loss of maize grains equivalent to $\$ 5,684.2$ per year due to post-harvest losses of maize in the study area. The adoption and scale-up of the dryer have implications in addressing maize post-harvest loss at the smallholder level and job creation for the youth in the country.
\end{abstract}

Keywords: Solar-biomass Hybrid Dryer, Post-harvest Loss Prevention, Cost-benefit Analysis, Job Creation

\section{Introduction}

Issues about high post-harvest losses and seasonality of food products have led to the development and introduction of improved and innovative ways to preserve food commodities [1, 2]. Several literature reviews have shown that drying of food products by the use of crop dryers is an effective and easy method that can be applied to many food crops to improve their shelf life and ensure availability during off-seasons. However, the process is a highly energy consumptive one that consumes a huge percentage of the total energy in the food industry. Energy sources such as fossil fuel and other electrical methods for drying are common but expensive [3]. The use of fossil fuel also poses a risk to the environment by the release of greenhouse gases
[4].

The traditional drying method which involves drying food products in the open sun is the most common in many parts of sub-Saharan Africa due to its low cost and operability. However, this method of drying is faced with some drawbacks that lead to severe qualitative and quantitative losses $[5,6]$. To improve the drying process using sun energy, conventional solar dryers have been introduced as a better alternative option to the traditional open-sun method for drying crops by farmers [7, 8]. Solar dryers provide better efficiency in terms of moisture removal and quality of dried food grains compared to the traditional open-sun drying method. Solar dryers also provide farmers with an option on affordability and they are environmentally friendly compared to commercial drying systems powered by fossil fuels or 
electricity [7, 9]. However, the commercialisation of conventional solar dryers has not been successful due to its high weather dependence. During periods of low incidence solar radiation, the performance of the system reduces leading to long drying periods [10]. According to Sekyere et al., [11], commercialisation of solar dryers in Ghana has generally not been successful with limited or non-adoption of such systems by farmers.

To address this problem and encourage the scale-up of solar dryers in sub-Saharan Africa and other parts of the world, the provision of reliable and readily available energy is required [2]. Due to this, current research works focus on the development of hybrid drying systems that rely on solar energy and other renewable energy sources such as biomass [12-14]. However, to scale up for the adoption of hybrid drying systems, information on its financial and economic viability is necessary to provide confidence to investors and early adopters of new technologies. In this regard, the financial and economic viability of operating a locally manufactured 1-tonne capacity tractor-mounted solar biomass hybrid dryer (SBHD) has been investigated.

\section{Materials and Methods}

\subsection{Description of the Dryer Unit and Study Area}

The newly developed prototype unit, as shown in Figure 1, is a greenhouse-type solar dryer and consists of three major parts, namely; the drying chamber, solar PV system, and biomass furnace. The parts are all fabricated together as a single unit and can be hitched to a tractor and wheeled from one place to the other to provide drying services to the smallholder maize farmers in a local farming community. This is similar to the operational concept of the mobile mechanical thresher largely used by smallholder maize farmers for threshing/shelling their grains in Ghana and other parts of Sub-Sahara Africa. The design capacity of the dryer is approximately $1000 \mathrm{~kg}$ of maize per batch.

The drying chamber has an overall dimension of $3 \mathrm{~m} \times 1.8$ $\mathrm{m} \times 1.9 \mathrm{~m}$ and is designed as a greenhouse tent dryer with the roof and sides of the drying chamber covered with a $0.03 \mathrm{~m}$ thick UV-protected transparent Acrylic sheet. The drying chamber is divided into seven levels (L1, L2, L3 ..., L7). Each level accommodates six (6) movable drying trays, each with a dimension of $0.9 \mathrm{~m} \times 0.8 \mathrm{~m} \times 0.05 \mathrm{~m}$. The trays are made from wood with the base of the trays fixed with perforated plastic mesh to hold the drying grain. The movable trays slide on a mild steel angle line frame and are spaced to allow for smooth flow of drying air on top and beneath the product preventing the need to stir during drying.

To ensures a continuous drying process in the dryer during periods of no sunshine or cloudy weather, a biomass furnace $(0.95 \mathrm{~m} \times 0.95 \mathrm{~m} \times 1 \mathrm{~m})$ with an in-built cross-flow heat exchanger is connected to the drying chamber to provide supplementary heat. Agro-residues such as maize cobs, dried coconut husk, rice husk, palm nut shells, etc. are the main feedstock burnt in the furnace to generate the required heat for drying grains in the dryer. In communities with no electricity access, the installed PV system with backup batteries provides electricity to supports the dryer operation.

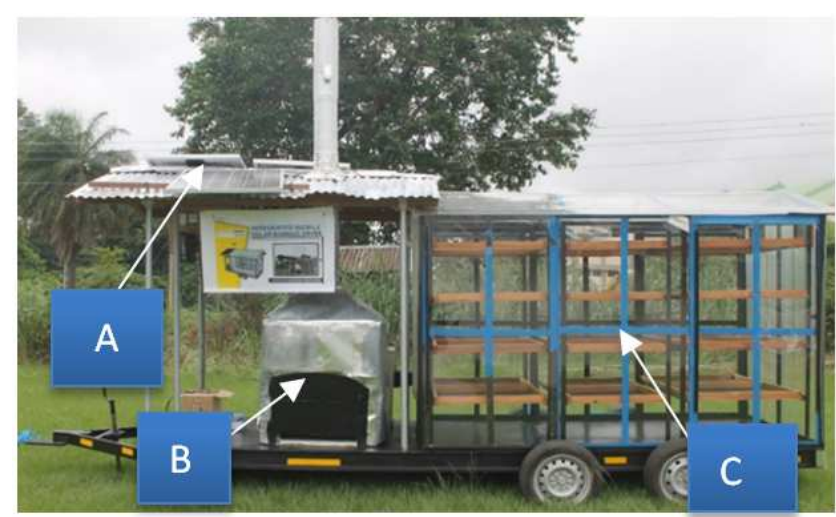

Figure 1. Developed mobile solar biomass hybrid dryer with Solar PV system. $A$ - Solar PV unit; $B$ - Furnace with enclosed heat exchanger and chimney; $C$ -Drying chamber with drying racks.

The study area was Ejura, the district capital of Ejura-Sekyedumase Municipal area, in the Ashanti Region of Ghana. The district is located about $100 \mathrm{~km}$ north of Kumasi, the Ashanti Regional capital and lies between Longitudes $1{ }^{\circ} 5^{\prime \prime} \mathrm{W}$ and $1^{\circ} 39^{\prime \prime} \mathrm{W}$ and Latitudes $7^{\circ} 9$ " $\mathrm{N}$ and $7^{\circ} 36^{\prime \prime} \mathrm{N}$ in the transitional zone of Ghana. The district experiences a mean monthly temperature of between $21^{\circ} \mathrm{C}$ to $30^{\circ} \mathrm{C}$, relative humidity between $90 \%$ to $55 \%$ and, a bi-modal rainfall pattern with an average rainfall of $1,200 \mathrm{~mm}-1,500 \mathrm{~mm}$ yearly. The district is among the leading maize-producing districts in the Ashanti Region that contributes about $60 \%$ of maize produced in Ghana. However, maize post-harvest loss in the district is estimated to be about 15 to $20 \%$ [15].

\subsection{Method of Data Collection}

Primary and secondary data were used for the study. Secondary information was accessed from various sources, including journals, articles, Ghana Statistical Services, and the Ministry of Food and Agriculture, the Bank of Ghana, and other online sources. The secondary data provided information about production and post-harvest loss data on maize for the study area, the average on-farm maize yield for the area, relevant financial indicators like interest rate, exchange rate as well as the minimum daily wage for unskilled labour in Ghana. Primary data was obtained mainly from personal interviews with dryer operators, smallholder farmers, and Agric Officers in communities in the study area. All technical details related to the study were from the 1-tonne capacity hybrid dryer. Some important information captured for the financial analysis includes capital expenditure for the installation of the dryer, the annual operating costs and revenue from the dryer operation, and the cost of a bag $(100 \mathrm{~kg})$ of dried maize. Other data collected include dryer performance data (drying rate, drying capacity), farm size of smallholder farmers in the district, membership of Farmer Based Organisations or Enterprise (FBO/FBE) in the study area, the daily wage paid for labour hands in the area. The data 
collected was limited to the 2019 production and marketing season. The main component that provides electrical power to the dryer is the solar PV system. It is often estimated to have a lifespan of 10 to 15 years. For this study, the cost and returns associated with the dryer operation were projected over 10 years lifespan.

The major capital costs captured in the financial analysis include the cost of the dryer, Solar PV system, biomass furnace, and blower with a motor. Labour and maintenance costs were captured under operating costs. Data on revenue was limited only to payment accrued from the dryer for drying maize in the study area. The cost and returns on the dryer operation are therefore limited only to maize drying.

\subsection{Analytical Approach}

Discounting methods for investment analysis, including net present value (NPV), internal rate of return (IRR), and benefit-cost ratio (BCR) were used to analyse the financial viability of the solar-biomass hybrid dryer. However, the undiscounted method (payback period) was used to determine how quickly the installed dryer generates enough funds to cover initial capital investments. Sensitivity analysis was carried out to establish changes in the viability measures due to variations in some key variables such as discount rate and drying charge during the dryer operation. Economic analysis was also performed to additionally highlight the potential for job creation for the youth in the study area from the scale-up of the hybrid dryer. The number of smallholder farmer-beneficiaries and potential economic loss of maize due to post-harvest loss prevented by using the dryer as against the traditional open-sun method was also estimated. The economic output indicators were determined with an analytical tool developed with the built-in-commands in Microsoft Excel.

\subsubsection{Net Present Value (NPV)}

NPV is a discounting method for evaluating the economic viability of investments and it simply refers to the present worth of the net cash flow of a firm. According to Adams et al., [16], NPV is the difference between the present value of an investment cash inflows (benefits) and the present value of the investment cash outflows (costs) at a given discount rate. A positive NPV indicates an economically feasible investment or project while a negative value shows that it is not economically feasible to carry out such an investment or project [17]. Mathematically, NPV is expressed as indicated in Equation 1.

$$
N P V=\sum_{t=0}^{N} a_{t} S_{t}
$$

Where:

$S_{t}$ is the net cash flow at a specific time $(t)$

$N$ is the number of years (10 years)

$a_{t}$ is the financial discount factor calculated using Equation 2

$$
a_{t}=\frac{1}{(1+i)^{t}}
$$

Where: $t$ is the time between 0 and $\mathrm{N}$

$i$ is the discount rate

\subsubsection{Internal Rate of Return (IRR)}

IRR is a measure of investment worth at which the discount rate which applies to an investment's cash flow produces a zero NPV. Generally, the higher the IRR the more desirable it is to undertake the project [18]. Mathematically, the IRR was calculated using Equation 3:

$$
N P V=\sum \frac{S_{t}}{(1+I R R)^{t}}=0
$$

\subsubsection{Payback Period (PBP)}

The payback period estimates the number of years it takes to recover an investment's initial capital. It provides a simple way to assess the economic merit of investments. Cash inflows for the PBP are undiscounted hence do not consider the time value of money. The payback period was mathematically expressed using Equation 4.

$$
P B P=\frac{C_{i}}{S}
$$

Where;

$C_{i}$ is the initial investment cost

$S$ is the net cash flow

\subsubsection{Benefit-cost ratio (BCR)}

This is the ratio of total discounted benefit to the total discounted cost of the investment cash flows. It measures the relative profitability of investment, unlike the NPV which accounts for total net benefits. According to Gittinger (1984) cited in Adams et al., [16], BCR becomes more relevant over the NPV when investors are interested in knowing the generated profitability from the amount invested in a business. Projects with a benefit-cost ratio greater than 1 have greater benefits than costs hence they have positive net benefits. The higher the ratio, the greater the benefits relative to the costs. Mathematically, the BCR was estimated using Equation 5.

$$
B C R=\sum\left(^{B_{i}} /(1+d)^{i}\right) \div \sum\left(C^{C_{i}} /(1+d)^{i}\right)
$$

Where

$B_{i}$ represents the benefit of the project in year $i, i=0$ to $\mathrm{n}$

$C_{i}$ represents the cost of the project in year $i$

$d$ represents the discount rate

\subsubsection{Sensitivity Analysis}

According to Saltelli et al., [19], sensitivity analysis is needed to assess the impact of changes in key variables of investment on NPV, IRR, BCR, and payback period. Adams et al., [16], also reported that sensitivity analysis helps to measure the effect of achieving investment objectives when the assumptions behind cash flows vary wholly or partially. In this study, a sensitivity analysis was performed to assess the impact of changes in the discount rate and drying charge on the key economic indicators. The discount rate is a key parameter that affects the NPV of a project. The drying charge 
is also considered a key variable for investment decisions in dryer installation for commercial operation as it relates directly to cash inflows. The sensitivity analysis was performed by varying the discount rate based on the policy rate trend of the last two decades of the Ghanaian economy. According to Bank of Ghana, [20], the policy rate has fluctuated from a minimum of $12.5 \%$ to a maximum of $27.5 \%$ since the last two decades.

\subsection{Methods of Data Analysis}

Descriptive analytical tools such as frequency tables and graphs were used to characterise the cost and returns from the use of the hybrid dryer for drying maize in the study area. The discounted methods of investment appraisal were also used to analyse the data.

\subsection{Assumptions}

To assess the viability of investment in the dryer business set-up using financial indicators such as NPV, BCR, IRR, and $\mathrm{PBP}$, the following assumptions were made in the financial and economic analysis. Grounds for the assumption were based on data from the performance of the dryer, prices obtained from the study area, and data from government and private agencies such as the Ghana Statistical Service and the Bank of Ghana. Maize is harvested in two seasons in a year in the study area; the major harvest season in which over $60 \%$ of maize produced by smallholder farmers in the area is harvested spans over a period of 3 months (June/July to August/September). This is the same period when the area experiences intermittent rainfall making it difficult for farmers to properly dry their harvested grains. The minor harvest season is limited to 2 months (November/ December to January/February) and it falls within the harmattan period so most farmers resort to drying their grains in the field or open space. As a result, the financial and economic analysis of the dryer business was based on the major harvest season at an operational period of 3 months in a year. Other major relative assumptions used in the financial and economic analysis include:

1) A dollar (USD) to Cedi (GHC) exchange rate of 5.7 was used for the analysis based on official foreign exchange rates in Ghana for January 2019.

2) The dryer is expected to operate at a full capacity of 1000 $\mathrm{kg}$.

3) Cash flows were discounted over 10 years based on the expected useable lifespan of the dryer.

4) A $10 \%$ annual increase in revenue was considered in the financial analysis based on the trend of increment in drying fees charged by commercial drying facilities set up in the study area.

5) The cost of capital used for the analysis is $24 \%$. This is based on the average lending rate offered by commercial banks in Ghana at the time of the study [20]. It is assumed an investor will borrow capital to set up the dryer business.

6) A rate of $2 \%$ of the investment cost is considered as maintenance cost in the financial analysis.

7) Two labour hands are considered adequate to operate the dryer at a wage of GHS 12.0 (US\$ 2.11) /labour. This was the daily minimum wage as of January 2020 in Ghana [21].

8) Labour cost is projected to increase by $10 \%$ each year based on the minimum wage trend in Ghana.

9) Electricity and fuel (biomass) costs are not considered in the operational cost analysis since maize cobs and husk is available and free in the study area. It is considered the main fuel that produces the heat required for the drying process. Electricity to run the blower is expected to be provided by the solar PV system.

\section{Results and Discussion}

\subsection{Economic and Financial Analysis of Hybrid Dryer Operation}

Economic and financial analysis are important means to assess the viability of any long-term project. Such analyses provide an opportunity to determine the benefits of such projects to investors and users. In this study, the economic and financial analysis of the 1-tonne capacity mobile solar-biomass hybrid dryer was investigated. Table 1 presents the financial and technical parameters used in the economic analysis of the dryer. Performance study of the dryer shows that a farmer can dry his maize grains from an initial moisture content of $22 \%(\mathrm{wb})$ to a safe moisture content of $13 \%(\mathrm{wb})$ in $7 \mathrm{~h}$ at an average drying rate of $1.3 \% / \mathrm{h}$. This translates to $1,008 \mathrm{~h}$ during the operational period of three months from June/July to August/September. This is the harvest period for the major production season of maize along the transition zone of Ghana where the study was conducted. The harvest time usually coincides with the onset of the peak rainfall season when smallholder farmers in particular, critically require drying services to dry their crops. Maize farmers in Ghana are typically smallholders and cultivate on an average farmland size of 2 ha or less with an average production output of 1.8 $\mathrm{t} / \mathrm{ha}$ of maize per cropping season. This corresponds to 3.6 tonnes ( $3600 \mathrm{~kg} / 36 \mathrm{bags})$ of maize produced by a farmer in the study area in a cropping season. This quantity of maize is projected to be dried within two operation days at an expected dryer operation of 2 batches in a day. This means the dryer would be available to other smallholder maize farmers who use the unreliable open-sun method for drying their maize particularly during the time open-air drying becomes challenging. Based on the specified capacity and the drying time of the dryer, it is estimated that 144 tonnes of maize (1,440 bags) are expected to be processed within the operational period of three months in a year. This translates into about 40 smallholder maize farmers (144 tonnes of maize $\div(2 \mathrm{ha} /$ smallholderfarmer $\times 1.8$ tonnes of maize/ha $)$ ) who could benefit directly from the dryer to dry their crops. This represents less than $1 \%$ of the total estimated production output of $30,266.80$ tonnes of maize produced by the smallholder farmers in the district. To support the other 
smallholder maize farmers in the area to meet their drying needs, it is projected that about 210 dryers of similar capacity are needed. This has the potential to create about 420 direct job opportunities for the youth in the area to provide drying services within the 3-month operational period.

At a likely post-harvest loss of 15 to $20 \%$ for grains dried in the open at market places or on the shoulder of roads in the area, the study postulates that a farmer loses about $\$ 3.95$ per bag of maize dried (minimum estimated quantity of grain lost $(15 \%)$ per bag $(100 \mathrm{~kg}) \times$ price per bag of maize dried $(\$ 26.32)$ $\div 100$ ) in the open particularly in the major harvest season when the drying of grains often coincides with intermittent rains resulting in mould infestation and other contaminations from pest and the droppings of scavenging animals. This study, therefore, postulates that if the projected 1440 bags of maize is dried using the dryer for the 3-month operational period, an estimated savings of $\$ 5,688$ (estimated quantity of maize dried per year by a dryer $(1440$ bags $) \times$ monetary value lost per a bag of dried maize due to post-harvest loss (\$3.95)) will be made per year due to post-harvest loss of maize prevented.

Table 1. Technical and financial parameters associated with the dryer operation.

\begin{tabular}{|c|c|}
\hline Parameter & Value \\
\hline Capacity of dryer $(\mathrm{kg})^{*}$ & 1000 \\
\hline Number of batches per day & 2 \\
\hline Number of hours required per batch of drying & 7 \\
\hline Number of operational days per week & 6 \\
\hline Number of operational hours per week & 84 \\
\hline Number of operational months per year & 3 \\
\hline Operational hours per year & 1008 \\
\hline Quantity of maize per bag ( $\mathrm{kg})$ & 100 \\
\hline Average on-farm maize yield per hectare & 1.8 \\
\hline $\begin{array}{l}\text { Average size of farmland (ha) for a typical smallholder maize } \\
\text { farmer }\end{array}$ & 2 \\
\hline $\begin{array}{l}\text { Average membership of a farmer-based organisation (FBO) in } \\
\text { the study area }\end{array}$ & 50 \\
\hline Number of bags of maize dried per day & 20 \\
\hline Number of bags of maize dried per week & 120 \\
\hline Quantity of maize dried per year $(\mathrm{t})$ & 144 \\
\hline Number of bags of maize processed per year & 1,440 \\
\hline Estimated production average of maize for the area $(\mathrm{t})$ & 30,266 \\
\hline Number of dryers required to process the total available maize & 210 \\
\hline Number of direct employments generated (persons) & 420 \\
\hline Lifespan of the dryer (yr.) & 10 \\
\hline Drying charged per bag of maize $(\$)$ & 2.11 \\
\hline Number of hectares of maize dried per year & 80 \\
\hline Number of smallholder farmer-beneficiaries & 40 \\
\hline Number of FBO beneficiaries & $\sim 1$ \\
\hline $\begin{array}{l}\text { Cost of purchasing a bag of dried maize }(\$) \text { in a local market in } \\
\text { the study area }\end{array}$ & 26.32 \\
\hline Estimated post-harvest loss in maize for the study area $(\%)$ & $15 \sim 20$ \\
\hline Economic loss per bag of dried maize due to post-harvest loss $(\$)$ & $3.95-5.26$ \\
\hline Monetary value of post-harvest loss prevented (\$) & 5,688 \\
\hline Exchange Rate (1\$ to GHS) & 5.70 \\
\hline
\end{tabular}

\subsection{Cost Analysis of Dryer Operation}

The initial capital expenditure used to establish the dryer is estimated as GhC 30,000 (US\$ 5,263.16). The main cost component is the material cost for the construction of the drying chamber and biomass furnace, estimated to be $70 \%$ of the total investment cost. The other initial capital expenditure is the solar PV system estimated to be $20 \%$ of the investment cost. Labour and overhead charges were about $10 \%$ of the total expenditure. According to Adams et al., [16], the overall capital demand to set up the dryer operation is consistent with the figure (less than US\$100, 000) reported by the World Bank for the classification of small-scale enterprises in Africa.

The cost associated with the operation and maintenance of the dryer is presented in Table 2. It represents the cost incurred after the capital expenditure period from year one to the tenth (10th) year of the dryer operation. An amount of GhC 6,648 (US\$1,166.32) is estimated as the total operating cost. This involves an amount of $\mathrm{GhC} 600$ (US\$105.26) representing 2\% of the total investment cost which is allocated for maintenance and overhead expenses. At a labour charge of $\mathrm{GH} \mathbb{C} 12$ (US\$2.11) per person for 4 hours of work per day, an amount of GhC 6,048 (US\$1,061.05) is estimated for salaries if two people are hired to operate the dryer for 14 hours per day during the 3-month operation cycle.

Table 2. Annual operating cost.

\begin{tabular}{ll}
\hline Item & Cost value (USD)/operation cycle \\
\hline Maintenance and overhead & 105.26 \\
expenses (2\% of investment cost) & $1,061.05$ \\
Salary of two operators & $1,166.32$ \\
Total running cost & \\
\hline
\end{tabular}

Official exchange: USD1 $=$ GhC5.7 as of January 1, 2020

For the sustainable operation of the dryer during the ten-year lifespan, the total operating cost is projected to increase annually at $10 \%$ due to price inflation in Ghana. Historically, prices of goods and services in Ghana have always experienced a slight variation due to inflation with an annual average of $10 \%$ [16]. The annual operating cost is therefore projected to increase from $\mathrm{GhC} 6,648.02$ (US\$1,166.32) to GhC 15,675.63 (US\$2,750.11) at the end of the $10^{\text {th }}$ year of operation.

\subsubsection{Revenue Analysis}

The design capacity of the hybrid dryer is $1000 \mathrm{~kg}$ per batch and is anticipated to operate at two batches per day. Given that the dryer will operate six (6) days per week for the 3-month operational period, it is expected that the dryer will be used to dry 144 tonnes (1440 bags) of maize per year. At a drying fee of GHC 12 (US\$2.11) per bag (100 kg) of maize dried, the total revenue of $\mathrm{GHC} 17,280$ (US\$3,031.58) is expected in the first operational year of the dryer. To match the rise in the operating and maintenance cost due to inflation, the drying fee is projected to also increase at $10 \%$ annually thereby resulting in an increase in revenue to GHC 25,451.24 (US\$ 4,465.13) at the end of the 10th year of operation of the dryer.

\subsubsection{Financial Viability Analysis}

According to Abbood et al., [17], a business is financially viable if the NPV is positive and the IRR is greater than the commercial discount rate of loans offered to investors. For this 
study, a discount rate of $24 \%$ was adopted as the opportunity cost of capital. This was the average interest rate charged on loans by commercial banks in Ghana at the time of the study [20]. The result of the financial analysis based on the discounted and undiscounted cash inflows and outflows of the dryer investment is presented in Table 3. It revealed that over a projected 10-year lifespan of the drying system, an NPV of GhC 27,793.43 (US\$ 4,876.04) and IRR of $38 \%$ can be achieved at a payback period of 2 years and 7 months after operations begin. The BCR (1.48) reported for this study is greater than one which implies that for every dollar invested in the dryer there will be a return of US\$ 1.48. The values of the financial viability indicators for this study demonstrate the feasibility of a business opportunity for an investor or a farmer to invest in owning and running the hybrid dryer as a business in the study area. In a similar study on profitability analysis of mango chips processing and cashew plantations in Ghana respectively, a similar trend in NPV and IRR values was the basis for a conclusion that small-scale mango chips processing business and cashew project is profitable and viable to invest in Ghana [16, 22]. Furthermore, Asante and Kuwornu [23], reported that investment in pineapple juice processing in Ghana is profitable and viable when their reported IRR (23\%) was greater than the discount rate which was $21 \%$.

Table 3. Projected operating cost for entire dryer investment.

\begin{tabular}{|c|c|c|c|c|c|c|c|c|c|c|c|c|}
\hline Item/Year & $\mathbf{0}$ & 1 & 2 & 3 & 4 & 5 & 6 & 7 & 8 & 9 & 10 & Total \\
\hline Total revenue & 0 & 3031.58 & 3334.74 & 3668.21 & 3851.62 & 4044.20 & 4125.09 & 4207.59 & 4291.74 & 4377.57 & 4465.13 & $39,397.46$ \\
\hline Total cost incurred & 5263.16 & 1166.32 & 1282.95 & 1411.24 & 1552.37 & 1707.60 & 1878.36 & 2066.20 & 2272.82 & 2500.10 & 2750.11 & $3,851.23$ \\
\hline Net cash flow & -5263.16 & 1865.26 & 2051.79 & 2256.97 & 2299.25 & 2336.60 & 2246.72 & 2141.39 & 2018.92 & 1877.47 & 1715.01 & $5,546.24$ \\
\hline Discounted factor & 1.00 & 0.86 & 0.74 & 0.64 & 0.55 & 0.48 & 0.41 & 0.35 & 0.31 & 0.26 & 0.23 & \\
\hline Discounted Revenue & 0 & 2613.43 & 2478.25 & 2350.07 & 2127.22 & 1925.5 & 1693.11 & 1488.77 & 1309.09 & 1151.1 & 1012.17 & $8,148.70$ \\
\hline Discounted Net cash flow & -5263.16 & 1607.99 & 1524.81 & 1445.94 & 1269.86 & 1112.49 & 922.15 & 757.69 & 615.82 & 493.69 & 388.77 & $4,876.04$ \\
\hline Net Present value & $4,876.04$ & & & & & & & & & & & \\
\hline Internal Rate of Returns & $38 \%$ & & & & & & & & & & & \\
\hline Benefit-cost ratio & 1.48 & & & & & & & & & & & \\
\hline Payback period & 2.67 & & & & & & & & & & & \\
\hline
\end{tabular}

\subsubsection{Sensitivity Analysis}

The potential for other farmers to invest in other similar small capacity drying systems in the area could pose a threat to the investment in the hybrid dryer business and affect revenue flow. One strategy to remain competitive is through a reduction in the drying fee charged ( $\$ /$ bag of maize) dried by the dryer. Additionally, an increase in operating cost and a potential rise in the discount rate or opportunity cost, a common trend in Ghana could also affect investment in the dryer business. The effect of decreased revenue due to reduced drying fees at $10 \%$ and $20 \%$, and a $10 \%$ increase in the operating cost on the financial indicators (NPV, IRR, PBP, and BCR) is presented in Table 4. The analysis of the results shows that the NPV, IRR, and BCR values decreased considerably when the drying fee charged per bag of maize dried was reduced by $10 \%$ ( $\$ 2.11$ to $\$ 1.89)$. The NPV decreased by $37 \%$ (from $\$ 4,876.04$ to $\$ 3,061.17$ ), IRR from $38 \%$ to $31 \%$, and BCR from 1.48 to 1.33 . The payback period however increased from 2.7 years to 3.2 years 2 . A similar trend is observed at a further reduction in the drying fee by $20 \%$ with the NPV drastically reducing to $\$ 1,246.30$ and the payback period going beyond 4 years. Though under both scenarios of revenue reduction the investment in the dryer is still viable and profitable, it however signifies that a reduction in the drying fee is sensitive to an investment in the dryer business. Similar results have been reported by Abbood et al., [17], who performed a financial analysis of a $1 \mathrm{MW}$ PV plant and observed that variations in the selling price of electricity considerably affected the NPV and IRR.

The effect of an increase in the operating costs by $10 \%$ showed a marginal variation in the financial indicators. As shown in Table 4, the NPV reduced marginally to $\$ 4,147.14$ while IRR reduced from $38 \%$ to $35 \%$ and $\mathrm{BCR}$ reduced to 1.39 from 1.48 .

Table 4. Effect of reduction in revenue and an increase in operating cost on NPV, IRR, PBP, and BCR.

\begin{tabular}{|c|c|c|c|c|}
\hline Stimulus & NPV (USD) & IRR (\%) & BCR & PBP \\
\hline $10 \%$ decrease in revenue & $3,061.17$ & 31 & 1.33 & 3.24 \\
\hline $20 \%$ decrease in revenue & $1,246.30$ & 22 & 1.18 & 4.12 \\
\hline $10 \%$ increase in operating costs & $4,147.14$ & 35 & 1.39 & 2.87 \\
\hline
\end{tabular}

The final sensitivity analysis was done to investigate the effect of variation in the discount rate on the financial indicators at a constant drying price of $\$ 2.11$ per bag of maize and the result is shown in Figure 2. The analysis shows that when the discount rate increases, the NPV decreases. This is an indication that business start-ups are affected negatively in an environment where the opportunity cost is too high. This does not provide confidence to investors who may have to take loans to invest in the dryer business. In all the scenario analyses, profitability measures for the investment in the dryer business were generally stable and profitable. 


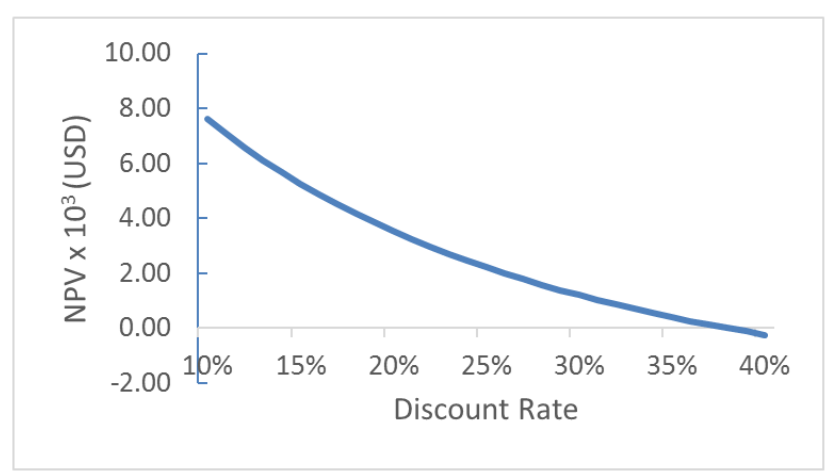

Figure 2. Effect of variations in the discount rate on the NPV.

\section{Conclusions}

The economic and financial viability of a 1-tonne capacity hybrid dryer for drying maize was successfully analysed using discounted and undiscounted investment appraisals methods such as NPV, IRR, BCR, and PBP.

The financial indicators of a case study show it is profitable and viable for an investment by a smallholder maize farmer or an investor to operate a dryer to provide drying services to maize farmers. The economic analysis over a 10 -year lifespan operation of the dryer resulted in an NPV of GhC 27,793.43 (US\$ 4,876.04), and an IRR of $38 \%$. Further analysis shows that at a drying charge of $\$ 2.11 / \mathrm{bag}$, the initial investment in the dryer can be recovered within a PBP of 2 years and 7 months with a BCR of 1.48. The sensitivity analysis on the dryer operation revealed that variations in revenue, operating costs, and the discount rate showed a slight vulnerability of the financial indicators. At an assumed $10 \%$ decrease in revenue and $10 \%$ increase in operation costs, the NPV reduced to $\$ 3,061.17$ and $\$ 4,147.14$ respectively. However, under both scenarios, the IRR was higher than the discount rate and the BCR greater than one. This is an indication of a positive outlook for investment in the dryer and it provides confidence for scale-up and adoption by smallholder maize farmers in Ghana.

Finally, the study postulates that to mitigate a probable $15 \%$ post-harvest loss of maize grain in the study area, about 210 of the hybrid dryers are required to meet the drying needs of the smallholder maize farmers who produce on average about 30, 266.80 tonnes of maize per production season. This translates into about 420 direct job opportunities for the youth to operate these dryers and provide real-time drying services and prevent the economic loss of grains equivalent to $\$ 1,195,507$ lost annually due to post-harvest loss of maize in the study area.

\section{Acknowledgements}

The authors will like to acknowledge the support received from Solidaridad Ghana for the construction of the dryer which was used for this study.

\section{References}

[1] Pardo, G. and Zufía, J. 'Life cycle assessment of food-preservation technologies', Journal of Cleaner Production, 28, (2012) pp. 198-207.

[2] Neba, F. A. and Nono, Y. J. Modeling and simulated design: A novel model and software of a solar-biomass hybrid dryer. Computers \& Chemical Engineering, 104, (2017) pp. 128-140.

[3] Wankhade, P. K., Sapkal, R. S. and Sapkal, V. S. Drying characteristics of okra slices using different drying methods by comparative evaluation. In Proceedings of the world congress on engineering and computer science, Vol. 2, (2012) pp. 24-26.

[4] Darvishi, H., Khoshtaghaza, M. H., Najafi, G. and Nargesi, F. 'Mathematical modeling of green pepper drying in microwave-convective dryer', Journal of agricultural science and technology, 15 (3), (2013) pp. 457-465.

[5] Madhlopa, A., Jones, S. A. and Saka, J. K. A solar air heater with composite-absorber systems for food dehydration. Renewable energy, 27 (1), (2002) pp. 27-37.

[6] Fudholi, A., Sopian, K., Ruslan, M. H., Alghoul, M. A. and Sulaiman, M. Y. 'Review of solar dryers for agricultural and marine products', Renewable and Sustainable Energy Reviews, 14 (1), (2010) pp. 1-30.

[7] Janjai, S. 'A greenhouse type solar dryer for small-scale dried food industries: development and dissemination. International Journal of Energy and Environment, 3 (3), (2012) pp. 383-398. ISSN 2076-2909 (Online), available at http://www.ieefoundation.org/ijee/vol3/issue3/IJEE_05_v3n3. pdf

[8] Kumar, M., Sansaniwal, S. K. and Khatak, P. 'Progress in solar dryers for drying various commodities', Renewable and Sustainable Energy Reviews, 55, (2016) pp. 346-360.

[9] Juneyd, F. D., Iqbal, H. J., Jhakimohammad, I. M., Prerak, S. P., Pankaj, S. B., Vatsal, M. P. A review paper on solar dryer. Int. J. Mod. Trends Eng. Res. 3 (3), (2016) pp. 143-152. ISSN (Online): 2349-9745, available at https://ijmter.com/papers/volume-3/issue-3/a-review-paper-on -solar-dryer.pdf

[10] Akpinar, E. K. 'Mathematical modelling and experimental investigation on sun and solar drying of white mulberry', Journal of Mechanical Science and Technology, 22, (2008) pp. $1544 \sim 1553$.

[11] Sekyere C. K. K., Forson F. K., Adam F. W. Experimental investigation of the drying characteristics of a mixed mode natural convection solar crop dryer with back up heater. Renewable Energy 92; (2016) pp. 532-542.

[12] Amer B. M. A., Hossain M. A., Gottschalk, K. Design and Performance Evaluation of a New Hybrid Solar Dryer for Banana. Energy Conversion and Management, 51, (2010) pp. 813-820.

[13] Gunasekaran, K., Shanmugan, V. and Suresh, P. (2012). Modelling and analytical experimental study of hybrid solar dryer integrated with biomass dryer for drying coleus forskohlii stems. IPCSIT, 28, pp. 28-32. Online, available at 006-CoimbatoreConferences-P0011.pdf (ipcsit.com). 
[14] Okoroigwe, E. C., Eke, M. N. and Ugwu, H. U. (2013). Design and evaluation of combined solar and biomass dryer for small and medium enterprises for developing countries. International Journal of Physical Sciences, 8 (25), pp. 1341-1349. Online, available at https://doi.org/10.5897/IJPS2013.3937.

[15] Ministry of Food Agriculture, MoFA (2020). Profile of Ejura Sekyeredumasi Municipal Assembly. Accessed September 17, 2019. Available https://mofa.gov.gh/site/sports/district-directorates/ashanti-reg ion/164-ejura-sekyeredumase

[16] Adams F., Amankwah K., Wongnaa C. A., Honny E. P., Peters D. K., Asamoah B. J. and Coffie, B. B., (2019). Financial analysis of small-scale mango chips processing in Ghana, Cogent Food \& Agriculture, 5:1, 167970. https://doi.org/10.1080/23311932.2019.1679701

[17] Abbood, A. A., Salih, M. A. and Mohammed, A. Y. (2018). Modeling and simulation of $1 \mathrm{mw}$ grid connected photovoltaic system in Karbala city. International Journal of Energy \& Environment, 9 (2), pp. 153-168. ISSN 2076-2909 (Online), available https://www.ijee.ieefoundation.org/vo19/issue2/IJEE_05_v9n2 .pdf
[18] Baum, W. C. and Tolbert, S. M. Investing in development: Lessons of World Bank experience (No. 332.1532 B3). New York: Oxford University Press. (1985).

[19] Saltelli, A., Ratto, M., Andres, T., Campolongo, F., Cariboni, J., Gatelli, D., Saisana, M., and Tarantola, S. (2008). Global sensitivity analysis: The primer. John Wiley \& Sons.

[20] Bank of Ghana, (2020). Policy rate trend in Ghana. Online, available https://www.bog.gov.gh/monetary-policy/policy-rate-trends/ (accessed on January 5, 2021).

[21] Statista. (2021). The daily minimum wage in Ghana. Retrieved from https://www.statista.com/statistics/1188375/daily-minimum-w age-in-ghana.

[22] Wongnaa, C. A., and Awunyo-Vitor, D. (2013). Profitability analysis of cashew production in Wenchi Municipality in Ghana. Bots. Journal of Agriculture and Applied Science, 9 (1), 19-23.

[23] Asante, M. K., and Kuwornu, J. K. M. (2014). A comparative analysis of the profitability of pineapple-mango blend and pineapple fruit juice processing in Ghana. Agroinform Publishing House, 8 (3), 33-42. 